九州大学学術情報リポジトリ

Kyushu University Institutional Repository

\title{
FIVE NEW SPECIES OF MISOLAMPIDIUS SOLSKY FROM JAPAN AND KOREA (COLEOPTERA, TENEBRIONIDAE)
}

Chujo, Michitaka

Imasaka, Shoichi

https://doi.org/10.5109/2424

出版情報: ESAKIA. 19，pp.123-134，1982-11-25. Entomological Laboratory，Faculty of Agriculture, Kyushu University バージョン :

権利関係 : 


\title{
FIVE NEW SPECIES OF MISOLAMPIDIUS SOLSKY FROM JAPAN AND KOREA (COLEOPTERA, TENEBRIONIDAE)*
}

\author{
M ichitaka Chôjồ \\ Hikosan Biological Laboratory, Faculty of Agriculture, \\ Kyushu University, Hikosan, Fukuoka 824-07, Japan \\ and \\ SHôICHI IM A S A K A \\ 1064 Shirachi-machi, Shimabara, Nagasaki 855, Japan
}

\begin{abstract}
A bstract
Two new species, Misolampidius koreanus and $M$. chejudoensis from Korea and 3 new species, M. adachii, $M$. gotoensis and $M$. sobosanus are described from Japan.
\end{abstract}

\section{Misolarnpidius koreanus sp. nov.}

Typically gourd-shaped, gently depressed, shining pitchy-black.

Male: Head nearly parallel-sided, sparsely punctate ; clypeus wholly depressed, roundly bent forwards, front margin very shallowly sinuate; gradually narrowing forwards ; frons roundly convex, medianly, shallowly depressed. Eye very slightly expanded outwards. Inner ocular groove very deep. Antenna comparatively stout; relative length of each segment (base to apex) $8: 4$ : $9: 7: 7: 7: 7: 7: 6: 6: 8$. Apical segment of maxillary palpus strongly securiform. Apical segment of labial palpus nearly oval. Mentum with deep, wide and longitudinal bigrooves, surface very roughly carved. Gular suture distinct, very stout.

Pronotum roundly convex, rather densely punctate; front margin nearly straight, front corner not angulate; side margin strongly, roundly expanded, faintly marginate at apical $1 / 3$, basal $1 / 7$ nearly parallel-sided; hind corner nearly rectangular, hind margin widely marginate. Propleuron very strongly, sparsely punctate. Scutellum weakly convex, side with very narrow margin reflexed, apex pointed. Prosternum very roughly carved, prosternal process tricostate, widest between front coxae, gently narrowing posteriorly.

Elytra strongly convex ; with fine punctate-striae ; interstices nearly flat,

* Contribution from the Hikosan Biological Laboratory, Faculty of Agriculture, Kyushu University, Hikosan (Ser. 3, No. 1). 
densely aciculate; basal margin simple, side margin very narrow. Epipleuron very narrow, reaching apex of elytra, apical $1 / 3$ of inner margin very narrow, reflexed. Mesosternum with V-shaped receptor of prosternal process very widely opened and shallow.

Every femur strongly clavate; dental projection of front femur trapezoidal; middle femur thickest at $8 / 11$ from base; hind femur thickest at about $10 / 13$ from base. Apical half of front tibia gently and roundly bent downwards at middle part, gradually dilated towards middle part, apical half nearly parallel-sided, apical 2/3 gently flattened, tibia1 spur triangular, short. Middle tibia clavate, weakly flattened. Hind tibia rather slender, gently dilated towards apex, weakly bent outwards at middle part. Sole of every tarsal segment densely pubescent; front tarsus with apical segment nearly as long as basal three segments put together; basal segment of hind tarsus nearly as long as apical one. First to 4 th visible abdominal sternites sparsely, finely punctate, apical segment densely punctate, apex truncate.

Paramere of male genitalia relatively thick, apical part distinctly sagittate, basal part weakly auriculate.

Female : Unknown.

Length : 13.3-15.0 mm. Width : 6.1-6.5 mm.

DistRIBUtion : $\boldsymbol{S}$. Korea.

Type material: Holotype ơ (Type No. 2374, Kyushu Univ.), Mt. Kongo, Korea, 18. VIII. 1940, T. Shirôzu leg. Paratype : đ^, Mt. Setsugaku, S. Korea, 24. VI. 1976, no collector's name.

This species is closely related to $M$. tentyrioides Solsky, 1875 from E. Siberia, but is clearly distinguished from the latter as follows:

\section{$M$ tentyrioides Solsky}

Body relatively elongate ; front femoral projection triangular ; front tibia with apical $1 / 4$ crooked in- and downwards, middle part of inside roundly expanded; apical $1 / 5$ of middle tibia weakly crooked inwards, apical corner of interior margin triangularly expanded. Basal piece of male genitalia nearly as long as paramere, apical part of paramere nearly sagittate.

\section{M. koreanus sp. nov.}

Body relatively rounded ; front femoral projection trapezoidal; front tibia with apical half nearly parallel-sided, gently bent downwards at middle part; middle tibia nearly straight, moderately clavate, thickest at $7 / 8$ from base. Basal piece of male genitalia nearly twice as long as paramere, apical part of paramere sagittate.

\section{Misolampidius chejudoensis sp. nov.}

Typically gourd-shaped, slightly depressed, stout, shining black.

Male : Head strongly punctate; clypeus sparsely, finely punctate, apical $1 / 3$ trapezoidal, roundly bent downwards, apex widely, shallowly sinuate ; clypeal suture very distinct; preocular area with basal half nearly parallel-sided; 

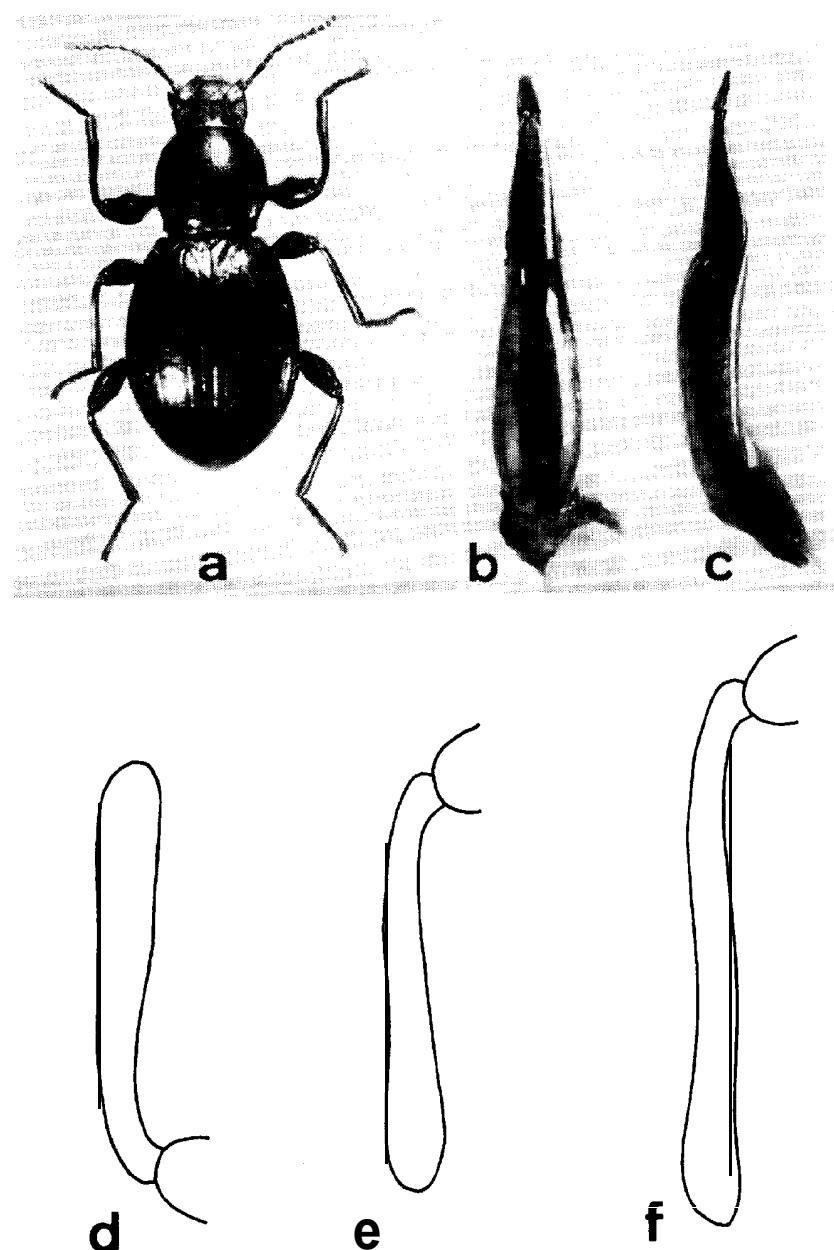

Fig. 1. Misolampidius koreanus sp. nov. a : Male, dorsal view. b. Male 'genitalia, dorsal view. c : Do., lateral view. $d$ : Dorsal view of mäle tront tibia.e : Dorsal view of male middle tibia. $\mathrm{f}$ : Dorsal view of male hind tibia.

frons roundly convex, with surface feebly undulate, median part with very shallow groove ; neck narrower than tempola. Eye nearly transverse, weakly, roundly expanded outwards ; inner ocular groove wide, very deep.

Antenna very stout, relative length of each segment (base to apex) $8: 4$ : $10: 7: 7: 7: 7: 7: 6: 6: 10$. Apical segment of maxillary palpus strongly securiform. Apical segment of labial palpus nearly oval. Mentum with deep and longitudinal semicircular grooves on both sides, surface roughly carved. Gular suture invisible. Tempola to gula extremely roughly and strongly carved.

Pronotum strongly convex, densely punctate; front margin transversely truncate, not marginate, front corner rounded; side margin very weakly marginate, sometimes incomplete; hind corner not angulate, hind margin widely 
marginate. Prosternal process roundly convex between coxal cavities, apex obtuse, a little projected backwards. Scutellum triangular, very sparsely punctate.

Elytra strongly convex, with strial punctures very fine and dense, interstices very slightly convex, very sparsely aciculate. Epipleuron narrow, reaching apex of elytra. Mesosternum wit I wide and shallow V-shaped receptor of prosternal process. Metasternum and metepisternum very sparsely aciculate. Fine punctures on visible abdominal sternite becoming gradually dense towards apex, every segment longitudinally wrinkled, apex transversely truncate. First to 2nd visible abdominal sternites weakly depressed at middle part. Apex
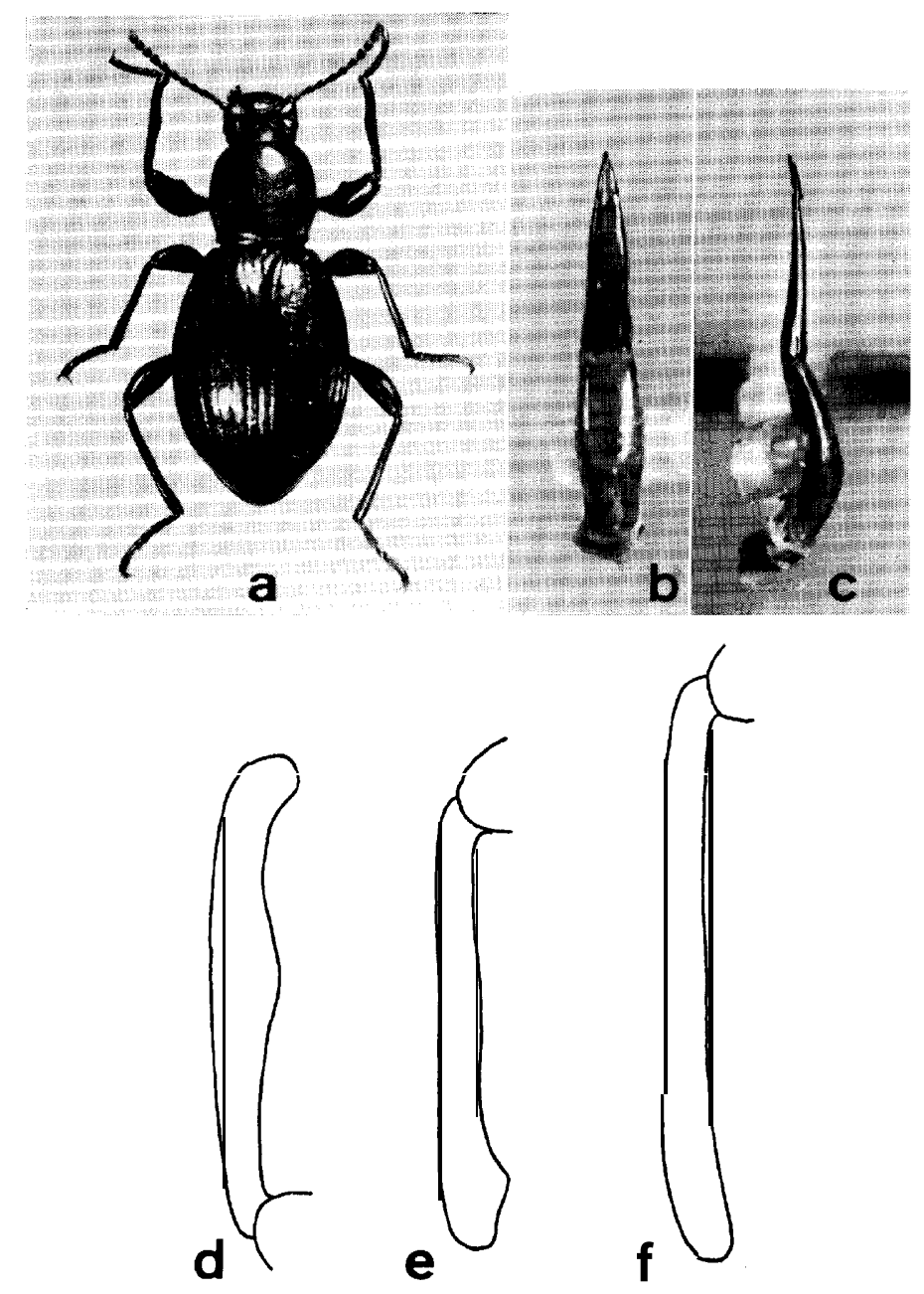

Fig. 2. Misolampidius chejudoensis sp. nov. a : Male, dorsal view. b : Male genitalia, dorsal view. c : Do., lateral view. d : Dorsal view of male front tibia. e : Dorsal view of male middle tibia. $f:$ Dorsal view of male hind tibia. 
of last visible abdominal sternite very slightly truncate.

Every femur strongly clavate, dental projection of front one triangular, middle one thickest at $2 / 3$ from base, hind one thickest at $3 / 4$ from base. Apical $1 / 5$ of front tibia crooked inwards, middle tibia gradually dilated towards apex, nearly straight, sometimes weakly warped outwards, inside of subapical part triangularly expanded; hind tibia weakly warped outwards, apical $1 / 3$ to $1 / 4$ weakly thickened, depressed and slightly crooked inwards. Apical segment of front tarsus nearly as long as rest put together; apical segment of hind tarsus much shorter than 1st and 2nd put together. Apex of last visible abdominal sternite slightly truncate.

Female: Generally smaller than male in size. Relative length of each antenna1 segment (base to apex) $8: 4: 9: 7: 7: 7: 7: 7: 6: 6: 10$. Front tibia gently dilated towards apex, apical $1 / 3$ feebly bent inwards; middle tibia gently dilated towards apex, very slightly warped outwards; hind tibia rather slender, very slightly warped outwards; apex of last visible abdominal sternite rounded.

Length : 13.8-15.8 mm. Width : 5.5-6.8 mm.

Distribution : Korea (Chejudo Island).

TyPe Material : Holotype : $\overbrace{}^{\rightarrow}$ (Type No. 2375, Kyushu Univ.), Shiitakegoya (800 m), Mt. Hanna, Chejudo Island, 14. VII. 1968, T. Shirôzu \& Y. Nishida leg. Paratopotypes : 7ðð, 2 우우, same data as holotype ; 4 $ð^{\Uparrow}, 2$ 우우, 14 . VII. 1968, S. Hidaka leg. ; đ, 15. VII. 1968, T. Shirôzu leg. ;6 ðð,3우, 15. VII. 1968, T. Shirôzu \& Y. Nishida leg.; 우, 16. VII. 1968, T. Shirôzu \& Y. Nishida leg. Paratypes : $2 \precsim ð$, Shiitakegoya (800 m)-Ryujinkaku (1,600 m), Mt. Hanna, Chejudo Island, 16. VII. 1968, T. Shirôzu leg. ; 우, Ryujinkaku (1,600 m), Mt. Hanna, Chejudo Island, 17. VII. 1968, T. Shrôzu leg.

This species is closely allied to M.tentyrioides Solsky, 1875 from E. Siberia and M.koreanus sp. nov. from S. Korea, but is easily distinguished from them by the following key:

1 Front femoral projection trapezoidal; front tibia with apical half nearly parallel-sided, gently bent downwards at middle part; middle tibia nearly straight, moderately clavate, thickest at $7 / 8$ from base koreanus sp. nov.

1 'Front femoral projection triangular ; front tibia with apical $1 / 4$ crooked in- and downwards, middle part of inside roundly expanded ; subapical part of middle tibia with inner expansion or crooked inwards

2 Antenna stout, relative length of each segment (base to apex) $10: 4: 10: 8:$ $7: 7: 7: 7: 6: 6: 10$. Aipcal $1 / 6$ of middle tibia crooked inwards, with inner expansion of subapical part at $7 / 8$ from base, apex of expansion angulate ; hind tibia with apical corner of interior margin weakly expanded inwards ......

tentyrioides Solsky

$2^{\prime}$ Antenna rather slender, relative length of each segment (base to apex) 9: $4: 9: 7: 7: 7: 7: 7: 6: 6: 10$. Apical part of middle tibia not crooked, with inner expansion at $13 / 16$ from base, apex of expansion rounded; hind tibia with apical corner of interior margin not expanded chejudoensis sp. nov. 


\section{Misolampidius adachii sp. nov.}

Stumpily gourd-shaped, shining black.

Male: Head nearly parallel-sided ; clypeus densely, finely punctate, apex weakly, roundly bent downwards, front margin very shallowly, widely sinuate; clypeal suture rather semicircular, deep; gena roundly narrowed forwards, not expanded outwards ; frons sparsely, strongly punctate, weakly convex. Eye rather transverse, very weakly, roundly expanded outwards ; inner ocular groove wide, deep. Gular suture invisible. Relative length of each antenna1 segment (base to apex) $9: 4: 10: 7: 7: 7: 7: 7: 6: 6: 9$. Apical segment of maxillary palpus moderately securiform. Mentum with longitudinal bigrooves very deep.

Pronotum roundly convex, strongly, roundly expanded outwards, strongly, densely punctate ; front margin transverse, not marginate, side margin vestigial, basal margin narrowly marginate. Propleuron rather densely punctate. Elytra strongly convex, strongly rounded outwards, with shallow and dense striate-punctures ; interstices nearly flat, densely aciculate. Epipleuron very narrow, reaching apex of elytra. Mesosternum with V-shaped receptor of prosternal process very wide, shallow. Apex of last visible abdominal sternite very slightly truncate.

Front femur with mountain-shaped dental projection on front margin, apex of projection rather sharp. Front tibia with apical 1/5 crooked inwards, middle $1 / 3$ of inside roundly expanded inwards; middle tibia slightly bent inwards at $1 / 3$ from base, apical $1 / 6$ very feebly crooked inwards, inside of subapical part with dull and thin dental projection; hind tibia very weakly dilated towards apex, feebly bent inwards at middle part., apical $1 / 7$ weakly crooked inwards. Apical segment of front tarsus nearly as long as 1st to 3rd put together; apical segment of hind tarsus nearly as long as 1st.

Paramere of male genitalia moderately auriculate just before base, sagittal part of apex not expanded outwards.

Female: Relative length of each antenna1 segment (base to apex) $9: 4:$ $9: 6: 6: 6: 6: 6: 5: 5: 8$. Front tibia weakly warped outwards, gently dilated towards apex ; middle tibia very slightly warped outwards, very weakly dilated towards $4 / 5$ from base, apical $1 / 5$ tapered; hind tibia very feebly bent inwards at middle part, apical $1 / 6$ slightly bent inwards. Apical segment of front tarsus nearly as long as 1st to 3rd put together; apical segment of hind tarsus nearly as long as 1st. Apex of last visible abdominal sternite rounded.

Length : 14.9-16.6 mm. Width : 6.2-6.3 mm.

Distribution: Japan (Tsushima Islands, Nagasaki).

Type material: Holotype $\lesssim$ (Type No. 2376, Kyushu Univ.), Mt. Mitake, Tsushima Is., 1. VI. 1972, K. Adachi leg. Paratopotype : , ஓ, same data as holotype ;2ðð, Mt. Tatera, Tsushima Is., 20. VI. 1961, M. T. Chûjô leg. 
This species is closely allied to M.tsushimanus Nakane, 1968 from Tsushima Islands, but is easily distinguished from the latter by the following characters : Subapical part of middle tibia with rather strongly projected inner

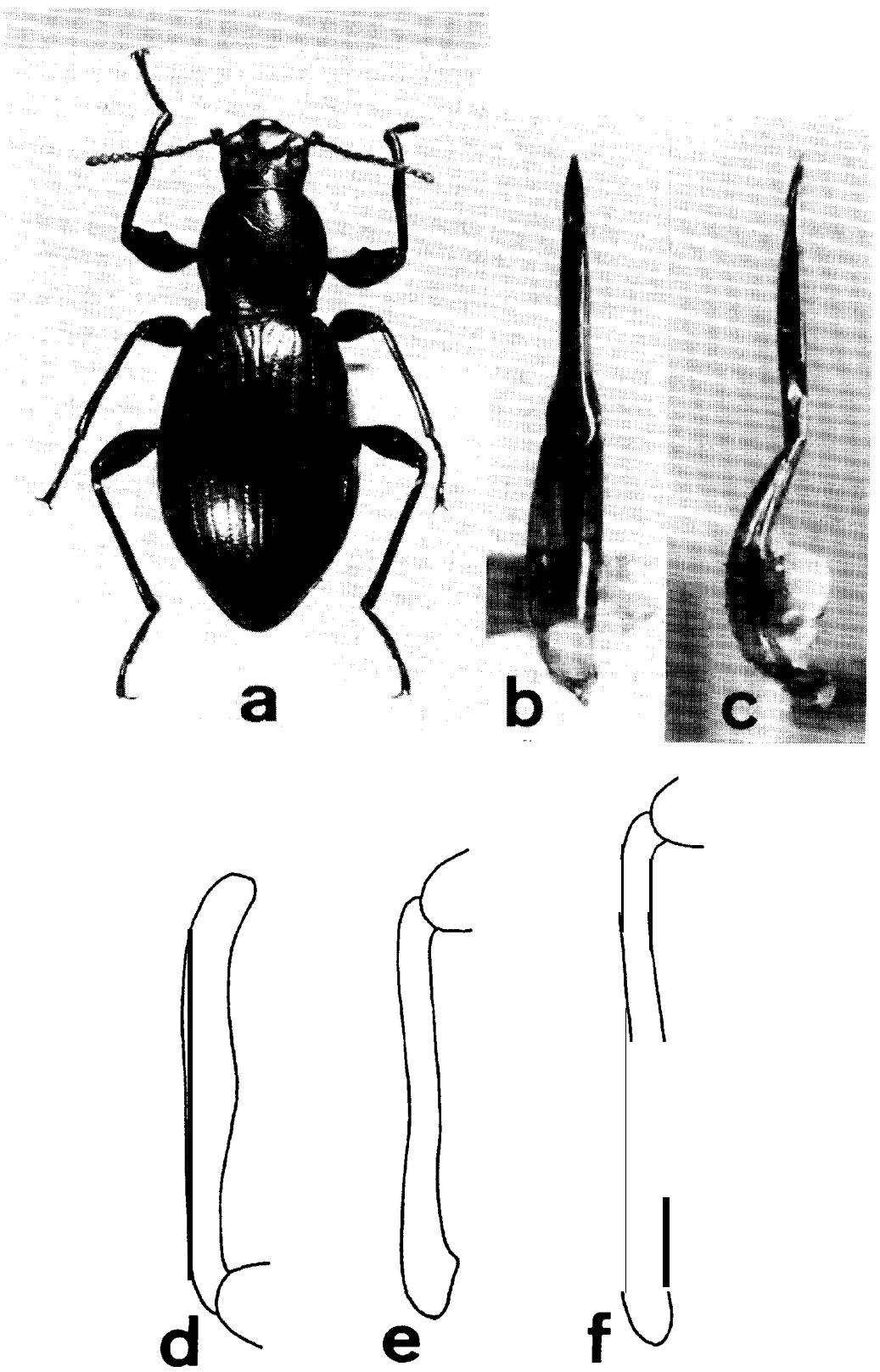

Fig. 3. Misolampidius adachii sp. nov. a : Male, dorsal view. b: Male genitalia, dorsal view. c : Do., lateral view. d : Dorsal view of male front tibia. e : Dorsal view of male middle tibia. $f$ : Dorsal view of male hind tibia. 
expansion, apex of expansion strongly angulate ; subbasal part of paramere of male genitalia rather distinctly auriculate.

\section{Misolampidius gotoensis sp.nov.}

Slimly gourd-shaped, moderately convex, piceous to black.

Male: Head rather rounded; clypeus gently bent downwards at apex, apex widely, very shallowly sinuate, densely punctate; clypeal suture narrow, shallow; gena rounded, not expanded outwards, middle part dark red ; frons gently convex, very strongly, densely punctate; neck rather slender. Eye comparatively large, rounded, weakly expanded outwards, inner ocular groove wide, shallow. Relative length of each antenna1 segment (base to apex) $9: 4: 10$ : $8: 8: 8: 7: 7: 6: 6: 9$. Maxillary palpus rather thick, apical segment moderately securiform. Labial palpus with apical segment rounded, securiform.

Pronotum strongly, densely punctate, side moderately expanded, widest at about $2 / 3$ from base ; side margin vestigial, hind margin widely marginate, sometimes intermitted at middle part. Prosternum sparsely punctate, apical margin narrowly marginate, rather moderately convex between coxal cavities, bigrooves of prosternal process shallow.

Elytra moderately convex, rather gently expanded outwards, with large striate-punctures ; interstices roundly convex, densely, finely punctate. Mesosternum with V-shaped receptor of prosternal process very shallow, wide. Apex of last visible abdominal sternite rounded.

Front femur with mountain-shaped dental projection on front margin, apex of projection obliquely truncate. Front tibia nearly straight, subapical part very feebly crooked inwards, middle part of inside weakly expanded; middle tibia very feebly warped inwards, with large spur at $7 / 9$ from base inside; hind tibia slender, very slightly bent outwards at middle part. Apical segment of front tarsus nearly as long as 1st to 3rd put together. Apical segment of hind tarsus a little longer than 1st. Male genitalia as seen in Fig. $4(b, c)$.

Female: Relative length of each antenna1 segment (base to apex) $8: 4:$ $9: 7: 7: 7: 7: 7: 6: 6: 10$. Front tibia very feebly warped outwards, very weakly dilated towards apex ; middle tibia nearly straight, inside of $2 / 9$ from base feebly expanded. Apical segment of hind tarsus much longer than basal one. Apex of last visible abdominal sternite rounded.

Length : $11.8-15.0 \mathrm{~mm}$. Width : 4.4-5.6 mm.

Distribution : Japan (Gotô Islands, Nagasaki).

Type materiad: Holotype $\sigma^{\star}$ (Type No. 2377, Kyushu Univ.), Mt Nanatsudake, Fukue I., Gotô Is., 4. I. 1968, H. Ishizuka leg. Paratypes: ðð, ơ, Mt. Nanatsudake, Fukue I., Gotô Is., 2. V. 1972, S. Kinoshita leg. (Coll. of Ent. Lab., Ehime Univ.) ; $ð, 4$ 우, Nozaki I., Gotô Is., 12. II. 1977, K. Yoshida leg. ; §. Mt. Nanatsudake, Fukue I., Gotô Is., 24. II. 1982, S. Imasaka leg. ; ${ }^{\star}$, 
Shiratori Shrine, Fukue I., Got8 Is., 24. II. 1982, S. Imasaka leg.

This species is closely related to M.clavicrus (Marseul, 1876) from Japan, but is distinguished from the latter by the following characters : Male genitalia with very narrow paramere and paramere much shorter than basal piece.
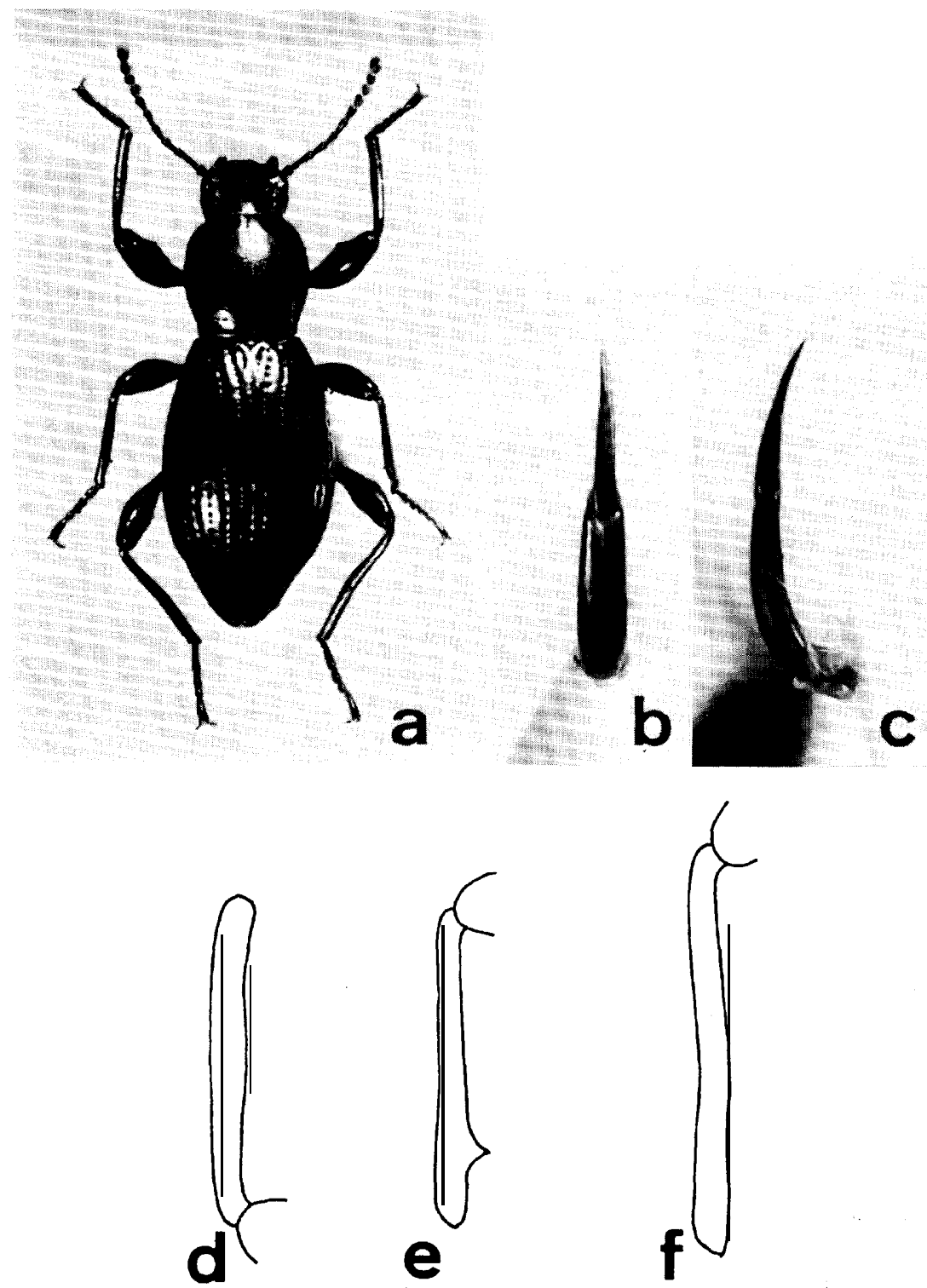

Fig. 4. Misolampidius gotoensis sp. nov. a : Male, dorsal view. b : Male genitalia, dorsal view. c : Do., lateral view. d : Dorsal view of male front tibia. e : Dorsal view of male middle tibia. $\mathrm{f}$ : Dorsal view of male hind tibia. 


\section{Misolampidius sobosanus sp. nov.}

Slimly gourd-shaped, rather small, piceous.

Male: Head nearly parallel-sided; clypeus sparsely punctate, nearly flat, apical margin widely, very shallowly sinuate; clypeal suture very narrow, shallow; side of gena rounded, not expanded outwards, middle part dark red; frons weakly convex, densely, strongly punctate. Eye comparatively large, roundly expanded outwards ; inner ocular groove rather wide, gently widened posteriorly. Gular suture invisible. Relative length of each antenna1 segment (base to apex) $9: 4: 11: 8: 7: 7: 7: 6: 6: 6: 8$. Maxillary palpus very thick. apical segment weakly securiform. Labial palpus oval.

Pronotum weakly convex, roundly expanded outwards, finely, densely punctate, with vestigial side margin at apical $1 / 5$, hind margin transversely truncate, widely marginate. Prosternum finely, sparsely wrinkled, front margin narrowly marginate, gently convex between coxal cavities, bigrooves of prosternal process very shallow.

Elytra weakly convex, moderately, roundly expanded outwards, a little narrowed near apex; with deep striate-punctures ; interstices moderately convex, sparsely aciculate, irregularly, finely wrinkled. Epipleuron narrow, reaching apex of elytra. Apex of last visible abdominal sternite very slightly truncate.

Front femur with large mountain-shaped dental projection, apex of projection obliquely truncate. Front tibia weakly warped outwards, middle part of inside feebly expanded; middle tibia nearly straight, inside with dull expansion at $9 / 11$ from base; hind tibia very slender, gently bent inwards at middle part. Apical segment of front tarsus nearly as long as 1st to 3rd put together; apical segment of hind tarsus much shorter than 1 st and 2nd put together.

Paramere of male genitalia weakly auriculate just before base, apical part invisibly sagittate.

Female: Relative length of each antenna1 segment (base to apex) $8: 4$ : $9: 7: 6: 7: 7: 6: 6: 6: 10$. Front tibia weakly, roundly warped outwards, gradually dilated towards apex, without inner expansion at middle part; middle tibia nearly straight, without any inner expansion at subapical part. Apex of last visible abdominal sternite rounded.

Length : 10.6-10.9 mm. Width : 3.9-4.0 mm.

Distribution : Japan (around the summit of Mt. Sobo, Kyushu).

Type material: Holotype ð (Type No. 2378, Kyushu Univ.), Mt. Sobo, Ôita, 2. VII. 1961, T. Kawatsu leg. Paratypes: $\widehat{\text { t }}$, Top of Mt. Sobo, Ôita, 22. VII. 1975, R. Noda leg.; ð, Mt. Sobo, Ôita, 23. VII. 1978, K. Adachi leg. ; 우, Mt. Sobo, Ôita, 1. VIII. 1979, T. Ogata leg.

This species is closely allied to M.clavicrus (Marseul, 1876) and M.goto- 

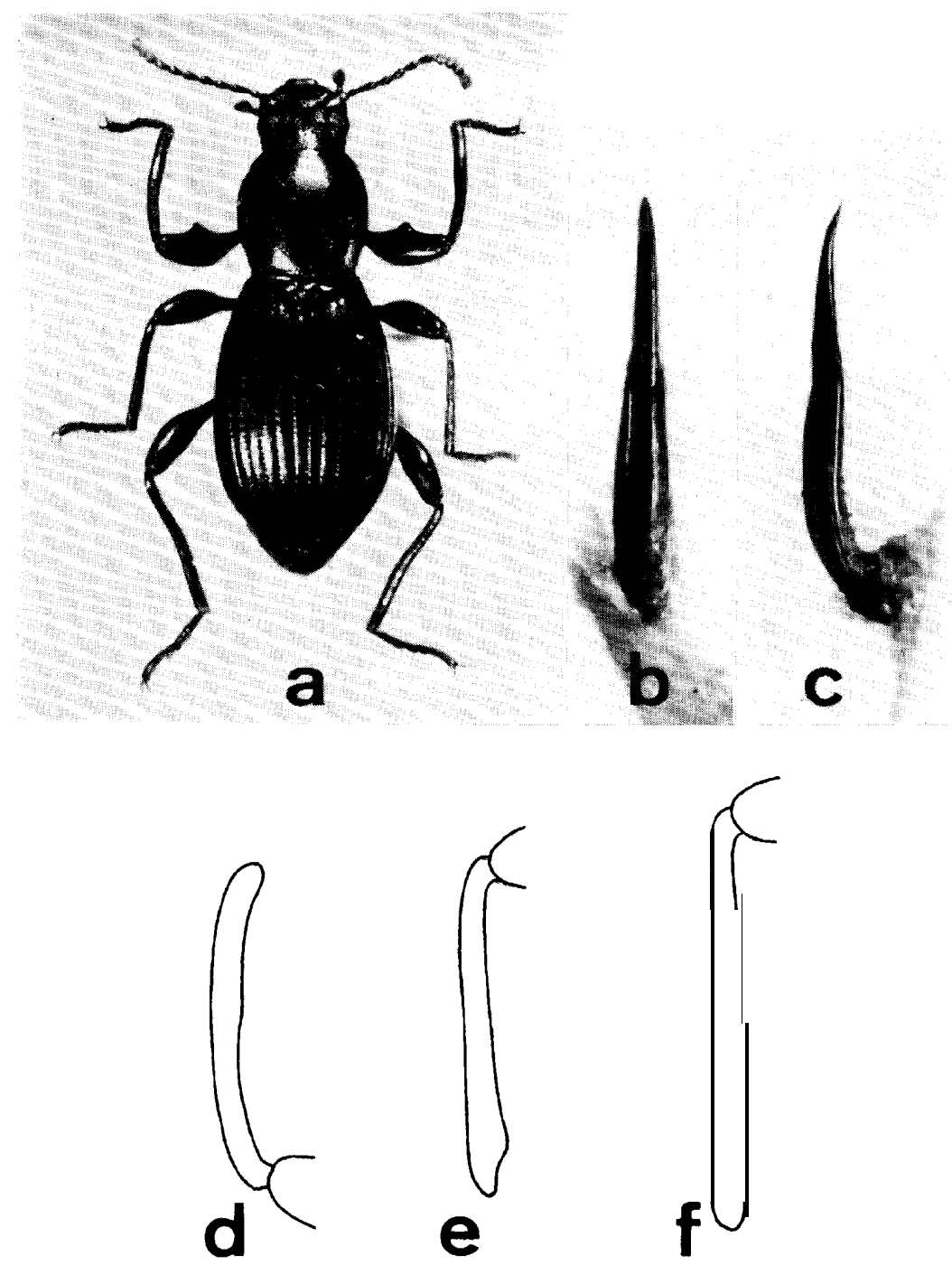

Fig. 5. Misolampidius sobosanus sp. nov. a : Male dorsal view. b : Male genitalia, dorsal view. c : Do., lateral view. d : Dorsal view of male front tibia. e : Dorsal view of male middle tibia. $\mathrm{F}$ : Dorsal view of male hind tibia.

ensis sp. nov. but is easily distinguished from them by the following characters: Middle tibia without large spur at subapical part of inside, and male genitalia shows quite different pattern.

\section{Acknowledgements}

We wish to express our appreciation to Prof Y. Hirashima, the head of Hikosan Biological Laboratory, for making this study possible. Also, we ex- 
press our cordial thanks to Prof. Emeritus K. Yasumatsu of Kyushu University, Prof. Emeritus M. Chûjô of Kagawa University and Prof. T. Nakane of Kagoshima University for their continual, kind and valuable advice. We are also grateful to Prof. Emeritus T. Shirôzu and Mr. R. Noda of Kyushu University, Mr. H. Ohishi of Kyoto and Mr. K. Yoshida of Saga who so kindly offered us many valuable specimens. Especial thanks are due to Mr. T. Shibata of Osaka and Mr. K. Kawada of Tokyo who kindly presented us all of their misolampid collections. And also, we express our thanks to Prof. T. Ishihara of Entomological Laboratory of Ehime University who kindly permitted us of examining valuable specimens under his care. 